OPEN ACCESS

Edited by:

Ashok Kumar

University of Florida, United States

Reviewed by:

Bo Zhou,

Stanford University, United States

Santosh Kumar,

University of Tennessee Health

Science Center, United States

*Correspondence:

Madhavan N. Nair

nairm@fiu.edu

Received: 03 July 2018 Accepted: 04 September 2018 Published: 27 September 2018

Citation:

Tiwari S, Atluri VSR, Yndart Arias A, Jayant RD, Kaushik A, Geiger J and Nair MN (2018) Withaferin A Suppresses Beta Amyloid in APP Expressing Cells: Studies for Tat and Cocaine Associated Neurological Dysfunctions. Front. Aging Neurosci. 10:291. doi: 10.3389/fnagi.2018.00291

\section{Withaferin A Suppresses Beta Amyloid in APP Expressing Cells: Studies for Tat and Cocaine Associated Neurological Dysfunctions}

\author{
Sneham Tiwari ${ }^{1}$, Venkata Subba Rao Atluri ${ }^{1}$, Adriana Yndart Arias ${ }^{1}$, Rahul Dev Jayant ${ }^{1}$, \\ Ajeet Kaushik ${ }^{1}$, Jonathan Geiger ${ }^{2}$ and Madhavan N. Nair ${ }^{1 *}$ \\ 'Institute of Neurolmmune Pharmacology, Center for Personalized Nanomedicine, Department of Immunology, Herbert \\ Wertheim College of Medicine, Florida International University, Miami, FL, United States, ²Biomedical Sciences, School \\ of Medicine and Health Sciences, University of North Dakota, Grand Forks, ND, United States
}

Neurological disorders are the biggest concern globally. Out of $\sim 36$ million human immunodeficiency virus (HIV) positive people, about 30\%-60\% exhibit neurological disorders, including dementia and Alzheimer's disease (AD) like pathology. In $A D$ or $\mathrm{AD}$ like neurological disorders, the pathogenesis is mainly due to the abnormal accumulation of extracellular amyloid beta $(A \beta)$. In this era of antiretroviral therapy, the life span of the HIV-infected individuals has increased leading towards increased neurocognitive dysfunction in nearly $30 \%$ of HIV-infected individuals, specifically older people. Deposition of the $A \beta$ plaques in the CNS is one the major phenomenon happening in aging HIV patients. ART suppresses the viral replication, but the neurotoxic protein (Tat) is still produced and results in increased levels of $A \beta$. Furthermore, drugs of abuse like cocaine (COc) is known to induce the HIV associated neurocognitive disorders as well as the $A \beta$ secretion. To target the Tat and coc induced $A \beta$ secretion, we propose a potent bifunctional molecule Withaferin A (WA) which may act as a neuro-protectant against $A \beta$ neurotoxicity. In this study, we show that WA reduces secreted $A \beta$ and induced neurotoxicity in amyloid precursor protein (APP)-plasmid transfected SH-SY5Y cells (SH-APP). In this study, we show that in SH-APP cells, A 3 secretion is induced in the presence of HIV-1 Tat (neurotoxic) and drug of abuse coc. Our fluorescent microscopy studies show the increased concentration of $A \beta 40$ in Tat $(50 \mathrm{ng} / \mathrm{ml})$ and $\operatorname{coc}(0.1 \mu \mathrm{M})$ treated SH-APP cells as compared to control. Our dose optimization study show, lower concentrations $(0.5-2 \mu \mathrm{M})$ of WA significantly reduce the $A \beta 40$ levels, without inducing cytotoxicity in the SH-APP cells. Additionally, WA reduces the Tat and cocaine induced $A \beta$ levels. Therefore, we propose that $A \beta$ aggregation is induced by the presence of Tat and $\mathrm{COC}$ and WA is potent in reducing the secreted $A \beta$ and induced neurotoxicity. Our study provides new opportunities for exploring the pathophysiology and targeting the neurological disorders.

Keywords: beta amyloid (A $\beta$ ), Withaferin A, HIV-1 Tat, cocaine, neurological disorders 


\section{INTRODUCTION}

The overall life expectancy of people living with human immunodeficiency virus (HIV; People living with HIV, PLWH) has increased moderately due to introduction of effective anti-HIV therapies (Oguntibeju, 2012; Sabin, 2013). As per WHO Number of AIDS related death decreased from 1.5 million (2010) to 1.1 million (2015) globally (World Health Organization, 2016). Longer drug (anti-retroviral) consumption and virus living cycle leads to increased prevalence of HIV-1 associated neurocognitive disorder (HAND; Saylor et al., 2016). Additionally, PLWH ( $\sim 2$ million as per World Health Organization, 2018) are more prone to the risk of developing neurological diseases like Alzheimer's disease and (AD)like neurocognitive problems. HIV-infection and associated neurological disease synergism has become a pressing health issue to be managed, globally' because HIV-infection progression facilitates AD like pathology (Koppel et al., 1985; Levy et al., 1985). Though, neurological disorders are irreversible but investigating novel therapies of better efficacy to manage these serious disorders without side-effects are urgently required.

$\mathrm{AD}$ is one of the prominent neurodegenerative disease, and is characterized as a progressive impairment of memory and neurocognitive functions due to abnormal accumulation of extracellular amyloid beta $(\mathrm{A} \beta)$ and intracellular neurofibrillary tangles (NFTs; Dorszewska et al., 2016). A $\beta$ aggregation is prominent in the cortical and limbic regions of the brain (Snider et al., 1983; Kurapati et al., 2013, 2014). Alternative or abnormal cleavage of integral membrane amyloid precursor protein (APP) by $\beta$ and $\gamma$ secretases (Ghosh et al., 2008; Guardia-Laguarta et al., 2010) lead to abnormal $A \beta$ processing, resulting into insoluble A $\beta$ aggregation (Zheng et al., 2002; Kretner et al., 2016). A $\beta$ peptides then aggregate into extracellular insoluble senile plaques (Echeverria et al., 2004; Guardia-Laguarta et al., 2010; Ahyayauch et al., 2012). This $A \beta$ accumulation leads to decreased neuronal health and stability, increased deterioration, synaptic depression (Venkitaramani et al., 2007; Palop and Mucke, 2010; Li et al., 2017), oxidative stress (Butterfield et al., 2013; Arimon et al., 2015; Cheignon et al., 2018), augmented neuronal dysfunctions and inflammation (Barage and Sonawane, 2015; Marottoli et al., 2017). These dysfunctions caused by $A \beta$ aggregation, become worst upon the presence of HIV-1 (András and Toborek, 2013; Martínez-Bonet et al., 2018) and drugs of abuse. HIV patients are reported to have augmented $\mathrm{A} \beta$ plaques deposition in the brain compared to HIV negative individuals (Esiri et al., 1998; Becker et al., 2004; Valcour et al., 2004). HIV associated $\mathrm{A} \beta$ dysfunction can be due to either the entire HIV virus, or mainly by neurotoxic Tat (transactivator of transcription) protein (Bagashev and Sawaya, 2013). HIV-1 Tat is neurotoxic and even though ART targets all the active virus, Tat could still be produced by the provirus in the viral reservoirs, such as brain (Daily et al., 2006). Tat protein as a neurotoxin, plays a prominent role in HIV neuropathogenesis as it gets secreted extracellularly and has the ability to cause neurotoxicity in the healthy cells (Chandra et al., 2005; Tahirov et al., 2010). Tat may have specific reaction with the $A \beta$ in the CNS and facilitate $A \beta$ aggregation, in the CNS (Hategan et al., 2017). Moreover, A $\beta$ aggregations are studied to be increased in cortex of HIV brains when compared to age matched non-HIV controls (Achim et al., 2009; Soontornniyomkij et al., 2012).

Another factor, which augments the $\mathrm{A} \beta$ aggregation induced pathogenesis, are the drugs of abuse (Ramage et al., 2005; Dublin et al., 2017). These powerfully addictive stimulant drug molecules have been studied to have an exaggerating effect during HIV infection (Jayant et al., 2017). Cocaine (coc), a very common abused drug within PLWH, exerts malicious effects on the CNS (Javadi-Paydar et al., 2017; Meade et al., 2017; Wakim et al., 2017). In the presence of coc, the additive effect of HIV-1 Tat and coc may increase $A \beta$ aggregation, which is a common factor in aging and HIV associated neurological disorders. Therefore, investigating desired therapies for coc abusing aging PLWH, are required for devising new therapeutic agent with multifunctional abilities to manage neurological disorders.

In this article, we have studied therapeutic properties of Withaferin A (WA) against multiple disease associated factors including $A \beta, H I V-1$ Tat and drug of abuse, coc. WA is an active purified drug moiety extracted from Ashwagandha (ASH), isolated from the root extract of a medicinal plant Withania Somnifera and expected to reverse $A \beta_{1-42}$ induced toxicity in human neuronal cells (Kurapati et al., 2013, 2014). WA is a steroidal lactone, derived from Withania somnifera (Indian Winter cherry or Ashwagandha). ASH has been traditionally used in ayurvedic medicine. WA is the first member of the withanolide class of ergostane type product to be discovered (Mirjalili et al., 2009). The beneficial effects of WA has been studied in the field of tumor inhibition (Bargagna-Mohan et al., 2007), antiangiogenic activity (Mohan et al., 2004; Challa et al., 2012; Mohan and Bargagna-Mohan, 2016), and against angioproliferative and malignant diseases like pancreatic cancer (Yu et al., 2010), leukemia, breast cancer and colon cancer (Choi and Kim, 2015), as well as anti-metastasis (Lee and Choi, 2016) and anti-carcinogenic properties (Rah et al., 2012). However, the therapeutic ability of WA against neurological disorders, as a protective agent is not well studied yet. WA is also explored in the field of apoptosis and adipogenesis inhibitor in 3T3-L1 adipocytes (Park et al., 2008). In this systematic study, we have explored for the first time the neuroprotective role of WA against $\mathrm{A} \beta$ secretion and aggregation in vitro. During our study we observed the deleterious effect of $A \beta$ on the neuronal health, function and morphology. In our step by step dose dependent studies, we explored the role of WA in reducing $A \beta$ induced neurotoxicity in the HIV-1 Tat and coc treated APP-plasmid transfected SH-SY5Y cells (SH-APP) cells, towards neurological dysfunctions. The outcomes of this research claim that WA has a great potential to be promoted as a natural neuro therapeutic agent in order to manage age or viral infection associated neurological disorders. Our studies open new areas of drug efficacy against neurological conditions.

\section{MATERIALS AND METHODS}

\section{Chemicals and Reagents}

Withaferin A (WA) was commercially purchased from Sigma Aldrich (Cat\# W4394 SIGMA). Methylthiazolyldiphenyl- 
tetrazolium bromide (MTT; Cat\# M2003) and paraformaldehyde was purchased from Sigma Aldrich. HIV-1 clade B recombinant Tat protein (86-amino acid) was obtained from NIH AIDS research and reference reagent program (Cat\# 2222).

\section{Cell Culture}

The cell type used in this study are SH-APP cells which is a human neuroblastoma cell line stably over-expressing human APP751 which was a kind gift from Dr. Jonathan Geiger (University of North Dakota, Grand Forks, ND, USA). SHAPP Cells were cultured in Dulbecco Eagle's minimum essential medium (DMEM; Gibco ${ }^{\circledR}$; Life Technologies, Grand Island, NY, USA) supplemented with $10 \%$ fetal bovine serum, $100 \mathrm{U} / \mathrm{ml}$ penicillin/streptomycin, nonessential amino acids, and sodium pyruvate $(1 \mathrm{mM})$ at $37^{\circ} \mathrm{C}$ in $5 \% \mathrm{CO}_{2}$.

\section{Cell Viability Assay}

Cells were plated at a density of $1 \times 10^{4}$ cells per well into 96-well plates and maintained at $37^{\circ} \mathrm{C}$ for $24 \mathrm{~h}$. Cells were treated with various concentrations of WA for $48 \mathrm{~h}$. Fresh medium containing $50 \mu \mathrm{L}$ of MTT solution $(0.5 \mathrm{mg} / \mathrm{mL})$ was added to each well. After $3 \mathrm{~h}$ incubation, the MTT formazan crystals were dissolved in dimethyl sulfoxide (DMSO) and viable cells were detected by measuring the absorbance at $570 \mathrm{~nm}$ using a microplate reader (Molecular Devices, Sunnyvale, CA, USA).

For Tat and coc toxicity study on cell viability, we performed Cell viability test using 0.4\% Trypan Blue Solution (T8154) Live dead screening. Ten microliter of cells were taken from the pellet resuspended in fresh media, after centrifugation at 1,500 rpm for $5 \mathrm{~min}$, and was mixed with $10 \mu \mathrm{l}$ of Trypan blue dye (1:1 ratio). The cells were then loaded on a cell counting slide and counted for live count on a cell counter (BioRad TC20 ${ }^{\mathrm{TM}}$ Automated cell counter)

\section{Tat and Coc Treatment of SH-APP Cells}

SH-APP cells $\left(1 \times 10^{6}\right.$ cells $)$ were cultured overnight in T-25 flasks in complete DMEM media with $10 \%$ FBS and 1\% Penicillin streptomycin solution. After $48 \mathrm{~h}$, cells were treated with different concentrations of HIV-1 Tat (5-100 ng/ml) and coc $(0.1-10 \mu \mathrm{M})$ and the cells and supernatant were collected after $48 \mathrm{~h}$ after the treatment. The optimized dose of Tat and coc were selected based on their effect on increasing $A \beta$ levels significantly compared to untreated controls. In further experiments, $1 \times 10^{5}$ $\mathrm{SH}$-APP cells were seeded in six wells plates and were cultured for $48 \mathrm{~h}$. Cells were treated with optimized concentrations of HIV-1 Tat1-72 and/or coc.

\section{Quantification of A $\beta 40$ Levels}

Secreted $A \beta$ levels were measured using human $A \beta 40$ ELISA kit as per the manufacturer's protocol (Thermo Fisher Scientific, Catalog\# KHB3481). For secreted A $\beta$ measurements, SH-APP cells were cultured in six well plates and after $48 \mathrm{~h}$, cells were treated with HIV-1 Tat/coc in combination with WA. The media from cultured cells was collected and protease inhibitor was added to it. The supernatant was utilized as samples for the $\mathrm{AB}_{40}$ ELISA as per the specific reagents and protocol provided with the kit. Each sample was analyzed in duplicate. Cells were saved for flow cytometry studies to estimate intracellular A $\beta 40$ level.

\section{Flow Cytometry}

Cells from Tat, $\operatorname{coc}^{+/-}$WA treated samples were utilized for flow cytometry studies. Flow Cytometry was used to identify the expression of $\mathrm{A} \beta 40$ protein in SH-APP cells after treatment with various concentrations of Withaferin A, Tat and coc. $1 \times 10^{6} \mathrm{SH}$-APP cells were stained with primary anti-human Aß40 (\#PA3-16760) and secondary anti-rabbit Fluorescein isothiocyanate (FITC)-labeled antibody (catalog \#AP187F, Millipore). Auto fluorescence of the cells was based on the unstained cells. Cells were gated based on the secondary antibody. Accuri BD flow and Amnis ${ }^{\circledR}$ Imaging Flow Cytometers were used for acquisition. Analysis was conducted in Flow Jo software and Amnis ${ }^{\circledR}$ FlowSight ${ }^{\circledR}$ Imaging Flow Cytometer and analysis by IDEAS ${ }^{\circledR}$ image software.

\section{Single-Cell Flow Cytometry}

The SH-APP were treated with different concentrations of WA. The cells were then harvested at $24 \mathrm{~h}$ after treatment, washed and counted; equal amounts of cells $(1 \times 106)$ were aliquoted in $1.5 \mathrm{ml}$ Eppendorf centrifuge tubes in $250 \mu 11 \times$ PBS. Cells were analyzed by ImageStreamX Imaging Flow Cytometer (Amnis Corporation, Seattle, WA, USA) having with INSPIRE software. A magnification of $60 \times$ was employed for all readings. Tenthousand cells (events) were analyzed for each sample. FITC and DAPI were excited with a $100 \mathrm{~mW}$ of $488 \mathrm{~nm}$ argon laser. FITC and DAPI fluorescence was collected on channel two (505-560 nm) and channel seven (560-595 nm), respectively. Intensity adjusted bright field images were collected on channel one. Bright field area and total fluorescence intensity were calculated using IDEAS software. Data analysis was performed using the IDEAS software (Amnis Corporation), with proper data compensation with respect to singly stained samples. The compensated data was then gated to eliminate cells that were out of field of focus and doublets or debris was eliminated too.

\section{Immunofluorescence Staining and Analysis for Studying Beta Amyloid Aggregation}

To study the effect of WA on the morphology aggregation, we conducted immunofluorescence imaging experiment. The cells were cultured to $80 \%$ confluency on the 4 -well microscopy slides and were then exposed to HIV-1 Tat+/- WA. After $48 \mathrm{~h}$, the supernatant was discarded and the cells were fixed in $4 \%$ PFA. PFA embedded slides were then immunostained by using A $\beta 40$ primary antibody (1:100) and GFP secondary antibody (1:100). Immunohistochemically stained sections were captured using the Keyence microscope. The images were captured at a magnification of $10 \times$.

\section{Immunofluorescence Staining for Studying Effect of WA on Neuronal Morphology}

To study the effect of WA on the neuronal morphology, we conducted immunofluorescence imaging experiment. The cells were cultured to $80 \%$ confluency on the 4well microscopy slides and were then treated with HIV-1 

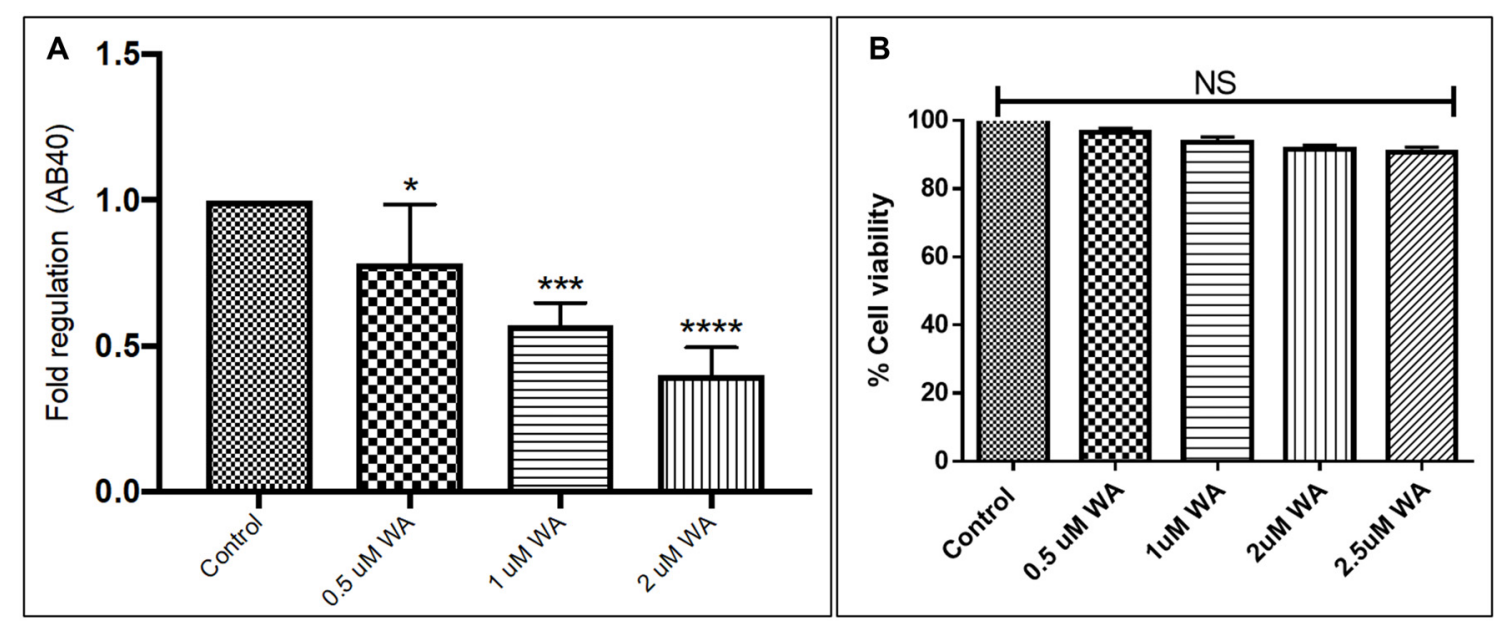

FIGURE 1 | Effect of Withaferin A (WA) on amyloid beta (A $\beta$ ) secretion. (A) Cells were treated with different dose of WA and the supernatants were collected $48 \mathrm{~h}$ after treatment. The supernatant collected were analyzed by $A \beta_{1-40}$ ELISA which demonstrated that at an optimum dose of $2 \mu \mathrm{M}$ WA, the levels of secreted A 40 showed significant decrease compared to control untreated samples. (B) The dosage of WA used for this experiment were also analyzed for the associated cellular toxicity. The cell toxicity assay showed that the lower doses of WA were not toxic to cells. Optimum dose of $2 \mu \mathrm{M}$, WA did not cause any loss in cell viability or toxicity in amyloid precursor protein (APP)-plasmid transfected SH-SY5Y (SH-APP) cells $\left({ }^{*} p \leq 0.05 ;{ }^{* * *} p \leq 0.001 ;{ }^{* * * *} p \leq 0.0001\right)$.

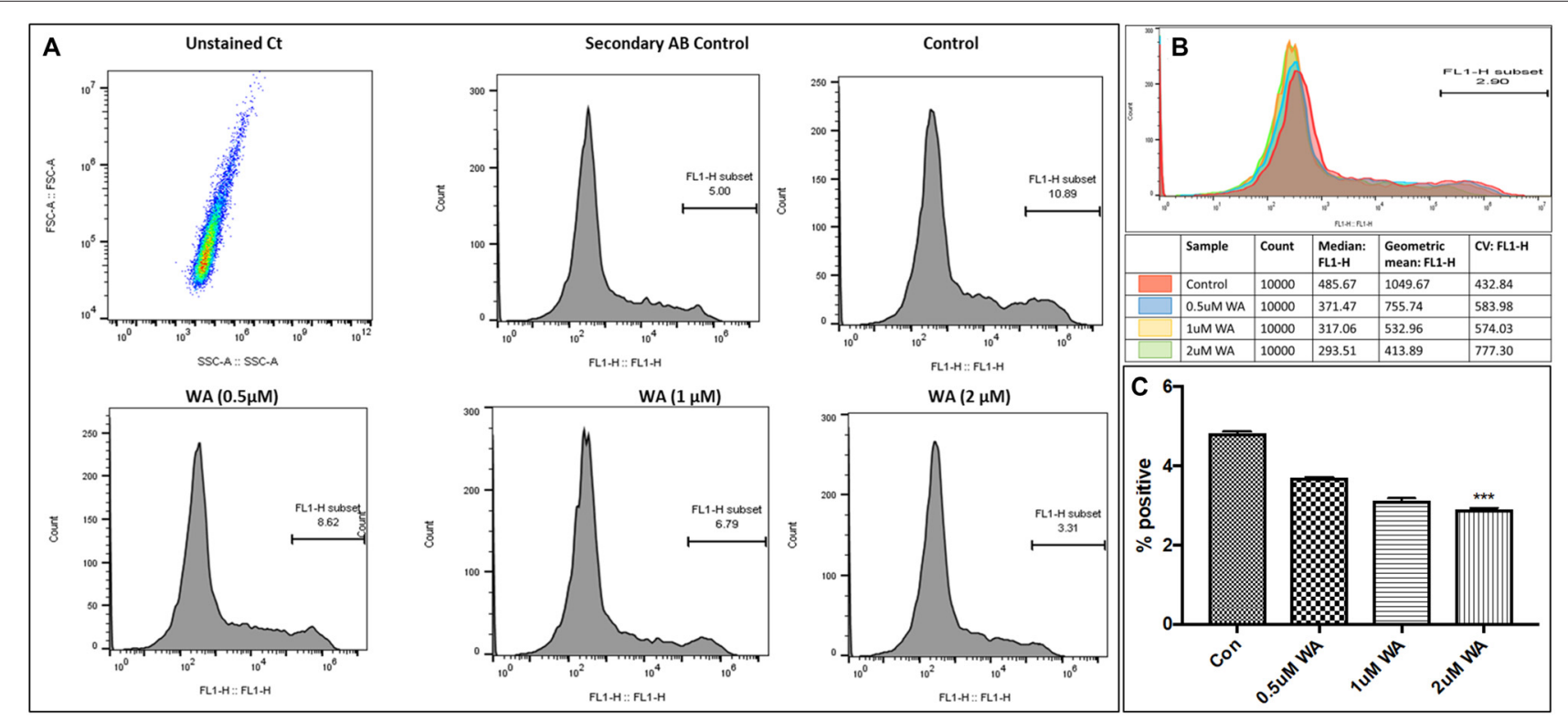

FIGURE 2 | WA inhibits $A \beta_{1-40}$ in concentration dependent manner. Panel $\mathbf{( A )}$ shows histograms of $A \beta$ secretion by the SH-APP cells upon treatment with varying dose of WA. Panel (B) shows the layover of the peaks in one histogram, and (C) shows the quantification of the same. The cells were treated with WA concentrations, and after $48 \mathrm{~h}$ of treatment were analyzed by Flow cytometry for determining $A \beta_{1-40}$ levels. Flow cytometry was used to identify the expression of $\mathrm{A} \beta_{1-40}$ in SH-APP cells after treatment with three different concentration of WA. $1 \times 106 \mathrm{SH}-\mathrm{APP}$ cells were stained with primary anti-human A 340 (\#PA3-16760) and secondary anti-rabbit Fluorescein isothiocyanate (FITC)-labeled antibody (catalog \#AP187F, Millipore). Auto fluorescence of the cells was based on the unstained cells. Cells were gated based on the secondary antibody. Accuri BD flow and Amnis ${ }^{\circledR}$ Imaging Flow Cytometers were used for acquisition. Analysis was conducted in Flow Jo software and Amnis ${ }^{\circledR}$ FlowSight ${ }^{\circledR}$ Imaging Flow Cytometer and analysis by IDEAS ${ }^{\circledR}$ Image software. For each experiment, from all events collected, FITC positive cells were gated from single cells $(* * * p \leq 0.001)$.

Tat protein/coc +/- WA. After $48 \mathrm{~h}$, the supernatant was discarded and the cells were fixed in 4\% PFA. PFA embedded slides were then washed and immunostained using MAP2 primary antibody (1:100) and anti-FITC secondary antibody (1:100). Immunohistochemically stained sections were captured using the ImageScope AT2 image scanner (Aperio Technologies) and analyzed using the ImageScope software; Scale $50 \mu \mathrm{m}$. 

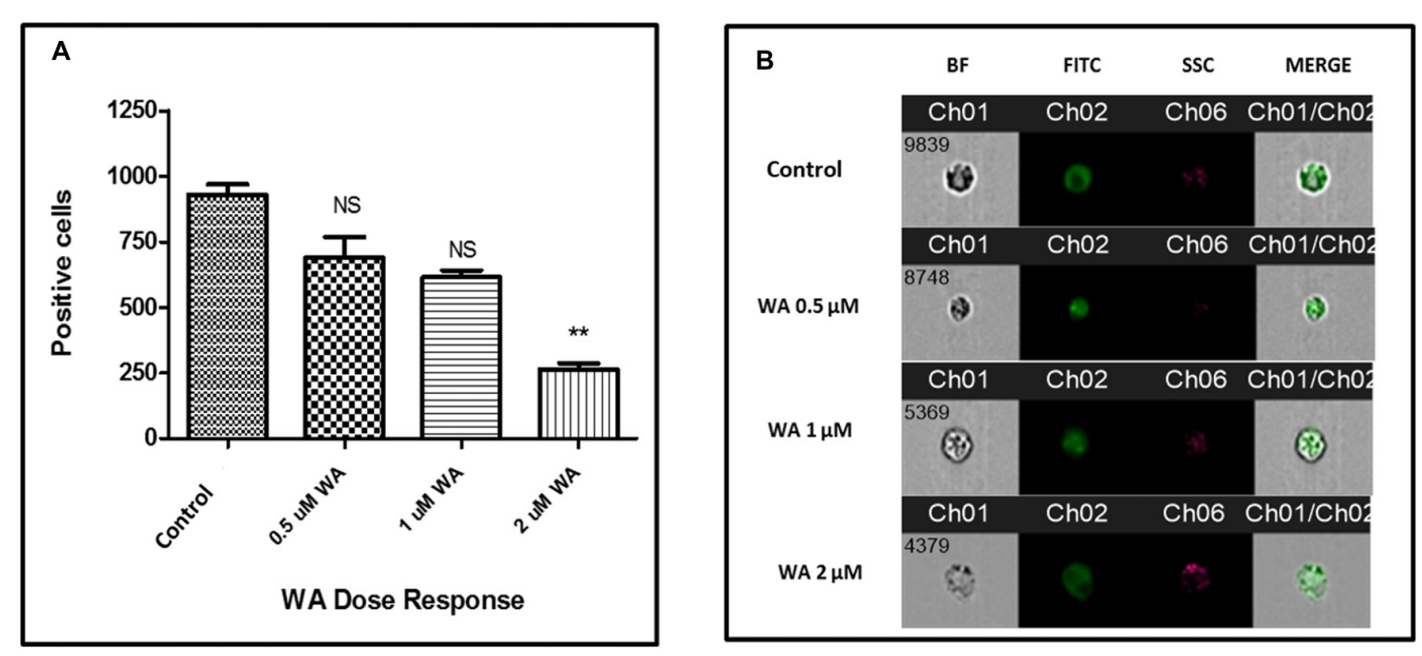

FIGURE 3 I WA inhibits A $\beta$ production: single cell flow Cytometry was used to identify the expression of A $\beta_{1-40}$ protein in SH-APP cells after treatment with different concentration of WA. (A) Bar graph representing the mean \pm standard error of percent of mean fluorescence intensity. (B) Representative single cell images. We have observed significantly reduced $A \beta$ with WA exposure dose dependently $\left(n=3 ;{ }^{* *} p \leq 0.01\right.$; NS: Non Significant).

\section{Data Analysis}

Results in this study are representative of three or more independent experiments. Statistical significance was analyzed using Graph Pad Prism5 software, La Jolla, CA, USA by performing ANOVA or the Student's $t$-test for unpaired observations. The values are presented as means \pm SEM.

\section{RESULTS}

\section{WA Dose Optimization and A $\beta$ Neutralizing Efficacy Studies in SH-APP Cells}

To optimize the non-toxic dose of WA, different concentrations of WA $(0.5-10 \mu \mathrm{M})$ were treated to SH-APP (neuroblastoma cell lines stably expressing human APP751) cells and results showed that $2 \mu \mathrm{M}$ of WA reduces the secreted AB40 in SH-APP cells significantly when compared to non-treated control, (Figure 1A) without inducing cytotoxicity to the cells (Figure 1B). Further, results were confirmed with the flow cytometry and showed (Figures 2A-C) dose dependent reduction in the $A \beta_{1-40}$ levels and the maximum reduction was reported at $2 \mu \mathrm{M}$ WA concentration without causing cellular toxicity. Additional single cell flow cytometry and imaging also showed the same trend highlighting the effective role of $2 \mu \mathrm{M}$ WA against $A \beta_{1-40}$ (Figures 3A,B).

\section{Effect of HIV-Tat Protein and coc on A $\beta$ Production in SH-APP Cells}

Human A 340 ELISA was performed with the supernatant collected from control and WA treated SH-APP cell samples
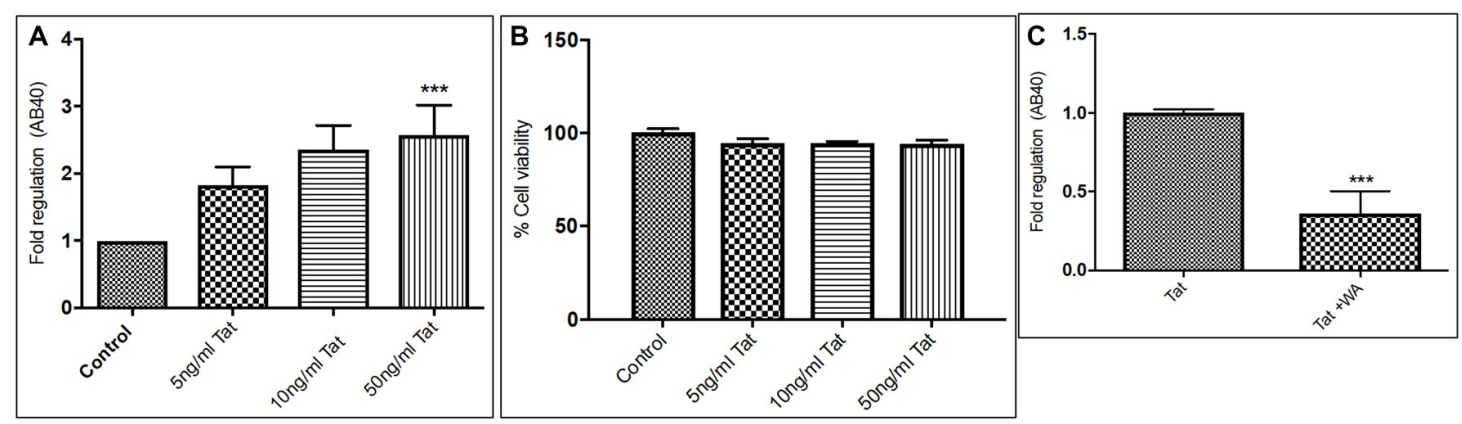

FIGURE 4 | Tat induce increase in secreted A 340 levels (A). Human Amyloid Beta ELISA analysis showing that Tat (5-50 ng/mL) increased the secreted $A \beta_{1-40}$ significantly in SH-APP cells. (B) Cellular toxicity assay showing viability of the cells in the Tat treated samples. (C) $2 \mu \mathrm{M}$ WA reduced the Tat levels significantly when compared to Tat $(50 \mathrm{ng} / \mathrm{mL})$ only treated samples. $1 \times 106 \mathrm{SH}$-APP cells were seeded in 6 -well plates and were grown for $48 \mathrm{~h}$ and then treated with human immunodeficiency virus (HIV)-1 Tat in different doses and the cells were then incubated for $48 \mathrm{~h}$ at $37^{\circ} \mathrm{C}$. The supernatant from the culture was collected and treated with protease inhibitor $(1 \mu \mathrm{l} / \mathrm{ml})$ and analyzed by $A \beta_{1-40}$ ELISA (Sigma). The results are from three independent experiments and the statistical significance was calculated by Student's $t$-test. Cell viability study was performed by Trypan blue live dead screening, to study the toxicity levels of various Tat dose. Dose selected for Tat treatment for further experiment was elected on the basis of increase in A $\beta 40$ secretion levels and correlated with cell viability (*** $p \leq 0.001)$. 

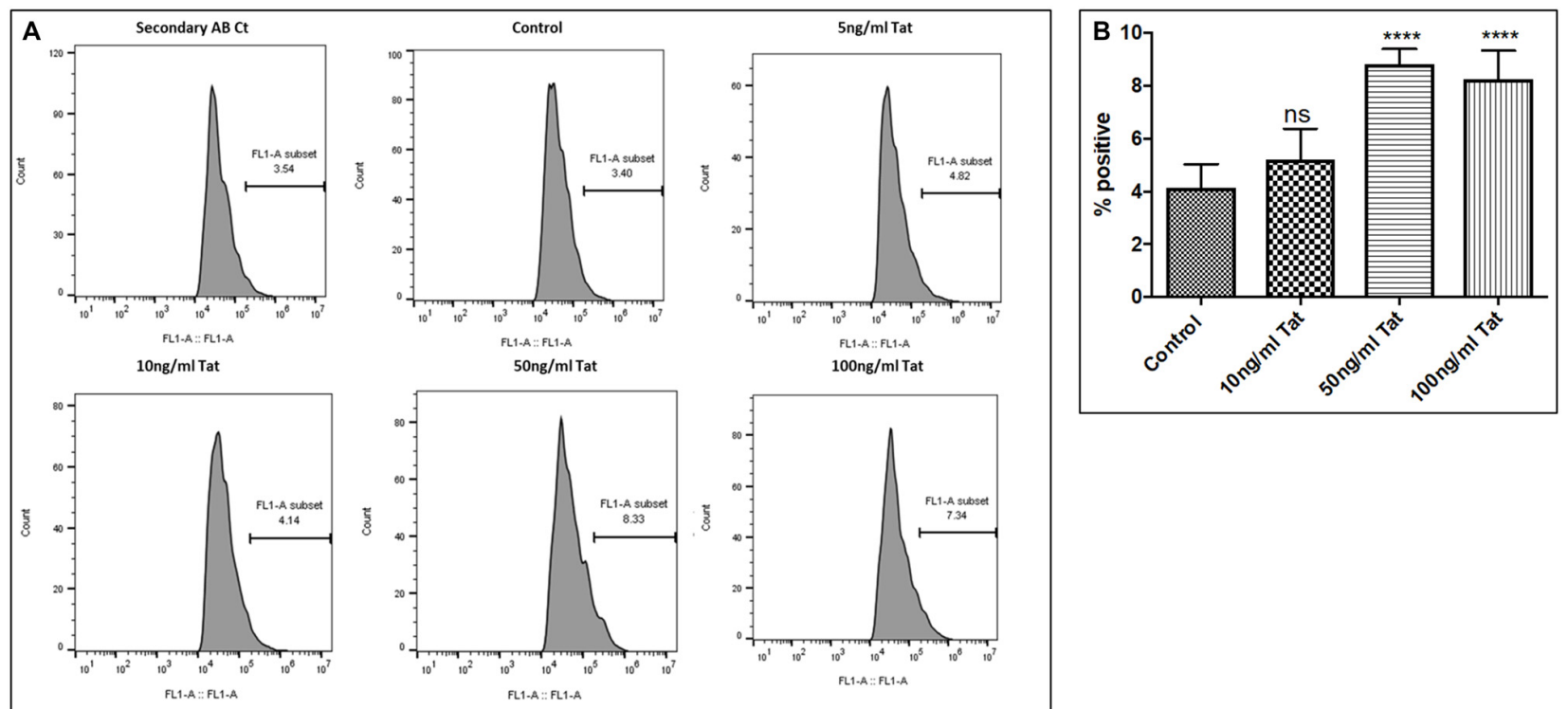

FIGURE 5 | Dose response. (A) Histograms showing Tat (5-100 $\mathrm{ng} / \mathrm{mL}$ ) increases the $A \beta_{1-40}$ levels. SHAPP cells were treated with different concentrations of Tat and after $48 \mathrm{~h}$ of treatment were analyzed by Flow cytometry for determining the $A \beta_{1-40}$ levels. (B) Quantification representation of the percent positive cells (**** $p$ $\leq 0.0001 ;$ ns: Non Significant).
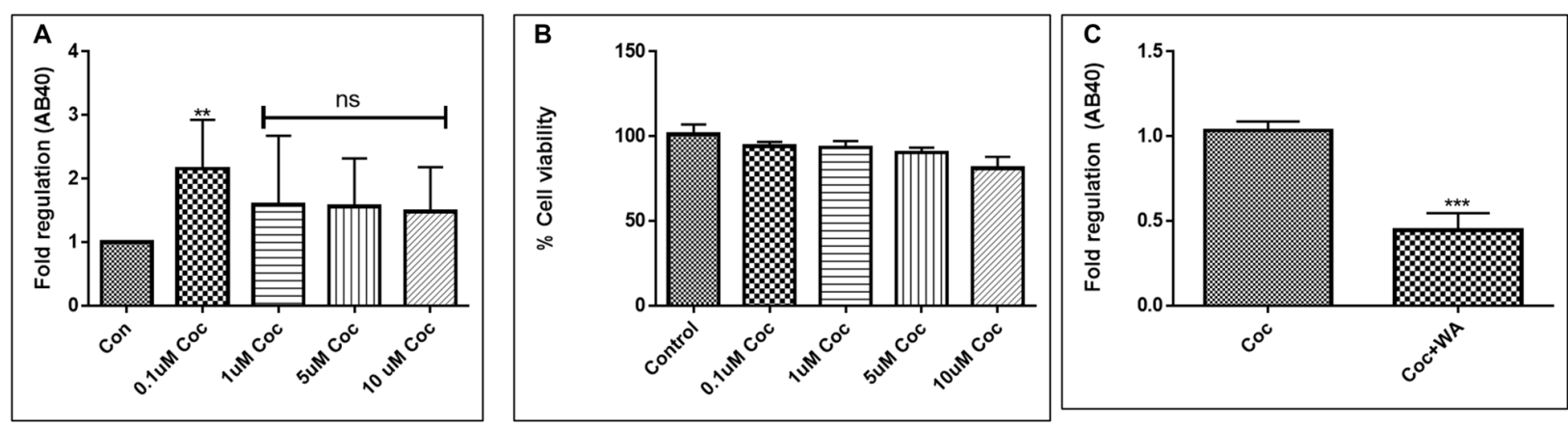

FIGURE 6 | Coc induces increase in secreted AB40 levels. Similar study pattern of ELISA and flow cytometry, like in the case of HIV-1 Tat, was performed with various concentrations of coc to choose an optimized dose of coc for further studies. (A) Coc increases $A \beta_{1-40}$ secretion. Coc $(0.1-10 \mu \mathrm{M})$ increased the secreted $A \beta_{1-40}$ but the significant increase was found in the samples treated with $0.1 \mu \mathrm{M}$ coc. (B) Cellular toxicity assay showing viability of the cells in the coc treated samples.

(C) $2 \mu \mathrm{M}$ WA reduced the $\operatorname{coc}(0.1 \mu \mathrm{M})$ induced $A \beta_{1-40}$ levels significantly when compared to coc only treated samples $\left(^{* *} p \leq 0.01 ; * * * p \leq 0.001\right.$; ns, not significant).

in order to evaluate the efficacy of WA in reducing the HIV-Tat and coc induced A $\beta$ secretion. SH-APP cells were treated with different concentrations of Tat $(5-50 \mathrm{ng} / \mathrm{ml})$ and $\operatorname{coc}(0.1-10 \mu \mathrm{M})$. Figure 4 shows that the SH-APP cells treated with Tat exhibited upregulation of $A \beta_{1-40}$ secretion compared to untreated control (Figures 4A,B). Effective dose of Tat $(50 \mathrm{ng} / \mathrm{ml})$ when treated with $2 \mu \mathrm{M} \mathrm{WA}$, showed significant decrease in $A \beta_{1-40}$ (Figure 4C). Further, the results were also confirmed by the flow cytometry using $A \beta_{1-40}$ specific primary antibody. The dose of $50 \mathrm{ng} / \mathrm{ml}$ Tat most significantly increased the $A \beta$ levels when compared to control (Figures 5A,B). Additionally, we studied the effect of coc in the similar study pattern, and observed the increase in $A \beta_{1-40}$ secretion (Figures 6A,B). We report that $0.1 \mu \mathrm{M}$ showed most significant upregulation in $\mathrm{A} \beta_{1-40}$ secretion compared to untreated controls. Effective dose of $\operatorname{coc}(0.1 \mu \mathrm{M})$ when treated with $2 \mu \mathrm{M}$ WA, showed significant decrease in $\mathrm{A} \beta_{1-40}$ (Figure 6C). This trend was also confirmed by the flow cytometry experiment which showed a coc induced increase in $A \beta$ levels (Figures 7A,B).

\section{Tat and coc Induced Increase in A $\beta 40$ Levels, in Combination}

An optimized dose of Tat $(50 \mathrm{ng} / \mathrm{mL})$ and $\operatorname{coc}(0.1 \mu \mathrm{M})$ alone or in combination were used to study the neutralizing efficacy of WA $(2 \mu \mathrm{m})$ in SH-APP cells. Results showed the combined effect of Tat and coc together in increasing the $A \beta_{1-40}$ levels. (Figures 8A,B). Individual optimized dose of Tat $(50 \mathrm{ng} / \mathrm{mL})$ 

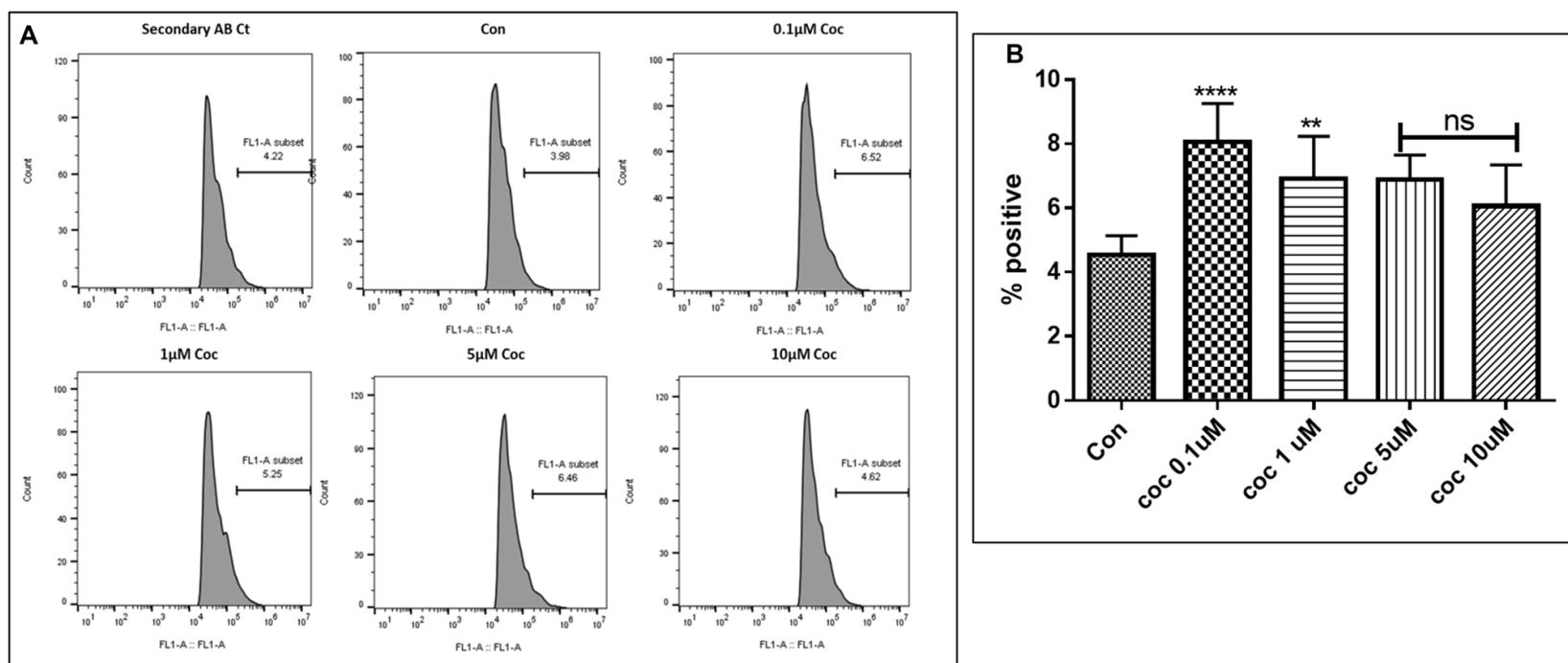

FIGURE 7 | Dose response. (A) Histograms showing $\operatorname{coc}(0.1-10 \mu \mathrm{M})$ increases the $A \beta_{1-40}$ levels. The cells were treated with different concentrations of coc and after $48 \mathrm{~h}$ of treatment were analyzed by flow cytometry for determining the $A \beta_{1-40}$ levels. (B) Quantification representation of the percent positive cells (** $p \leq 0.01$; **** $p \leq 0.0001 ;$ ns, not significant).

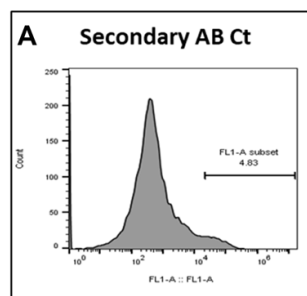

Tat

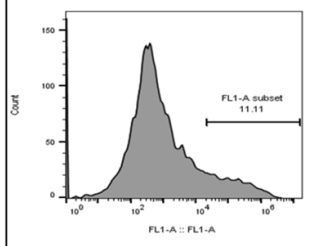

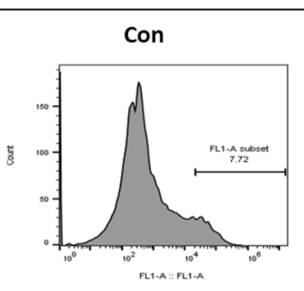

Tat+Coc

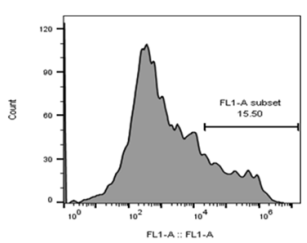

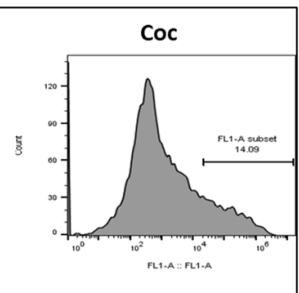

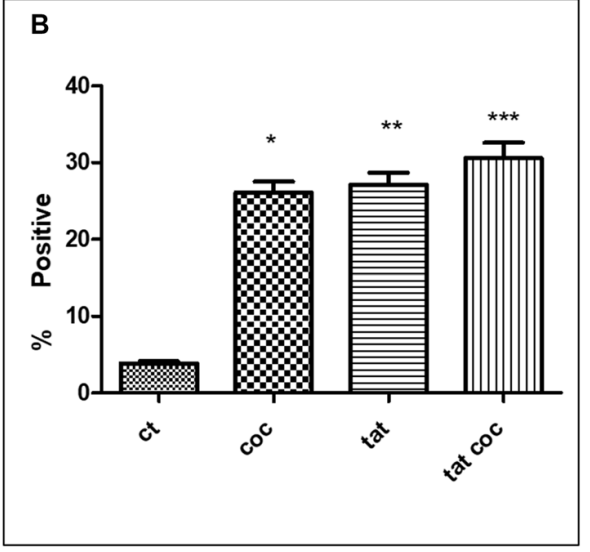

FIGURE 8 | Tat and coc combination. (A) Tat $(50 \mathrm{ng} / \mathrm{mL})$ and $\operatorname{coc}(0.1 \mu \mathrm{M})$ individually and in combination increase the $\mathrm{A} \beta_{1-40}$ levels. The cells were treated with selected Tat and coc concentrations and combination of both, and after $48 \mathrm{~h}$ of treatment were analyzed by flow cytometry for determining the A $\beta_{1-40}$ levels. (B) Quantification representation of the percent positive cells $\left({ }^{*} p \leq 0.05 ;{ }^{* *} p \leq 0.01 ;{ }^{* * *} p \leq 0.001\right)$.

and $\operatorname{coc}(0.1 \mu \mathrm{M})$ were used for further WA neutralizing efficacy studies from here on.

\section{WA Reverses Tat and coc Induced Amyloid Aggregates in vitro}

Immunocytochemistry studies showed that WA was able to reduce the amyloid aggregation when compared to the untreated control SH-APP cells. The cells were grown in the microscopic slides (eight wells) and after $24 \mathrm{~h}$ of growth, the wells were treated individually with Tat $+/-$ WA and coc $+/-$ WA for $48 \mathrm{~h}$ and control wells had fresh media added. The cells were then collected, fixed and stained with primary Beta amyloid 1-40 antibody (1:100) and GFP secondary antibody (1:100). We observed that the cells exposed to Tat and coc had strong signals for amyloid beta aggregations, which was mitigated by WA treatment as seen in the Tat + WA and coc + WA microscopic chambers, when compared to control well (Figures 9A-G).

\section{WA Reverses/Decreases coc Induced Neurotoxicity}

Additionally, to study derogatory effects of coc on the SH-APP cells and the effect of WA on the neuronal morphology, we 

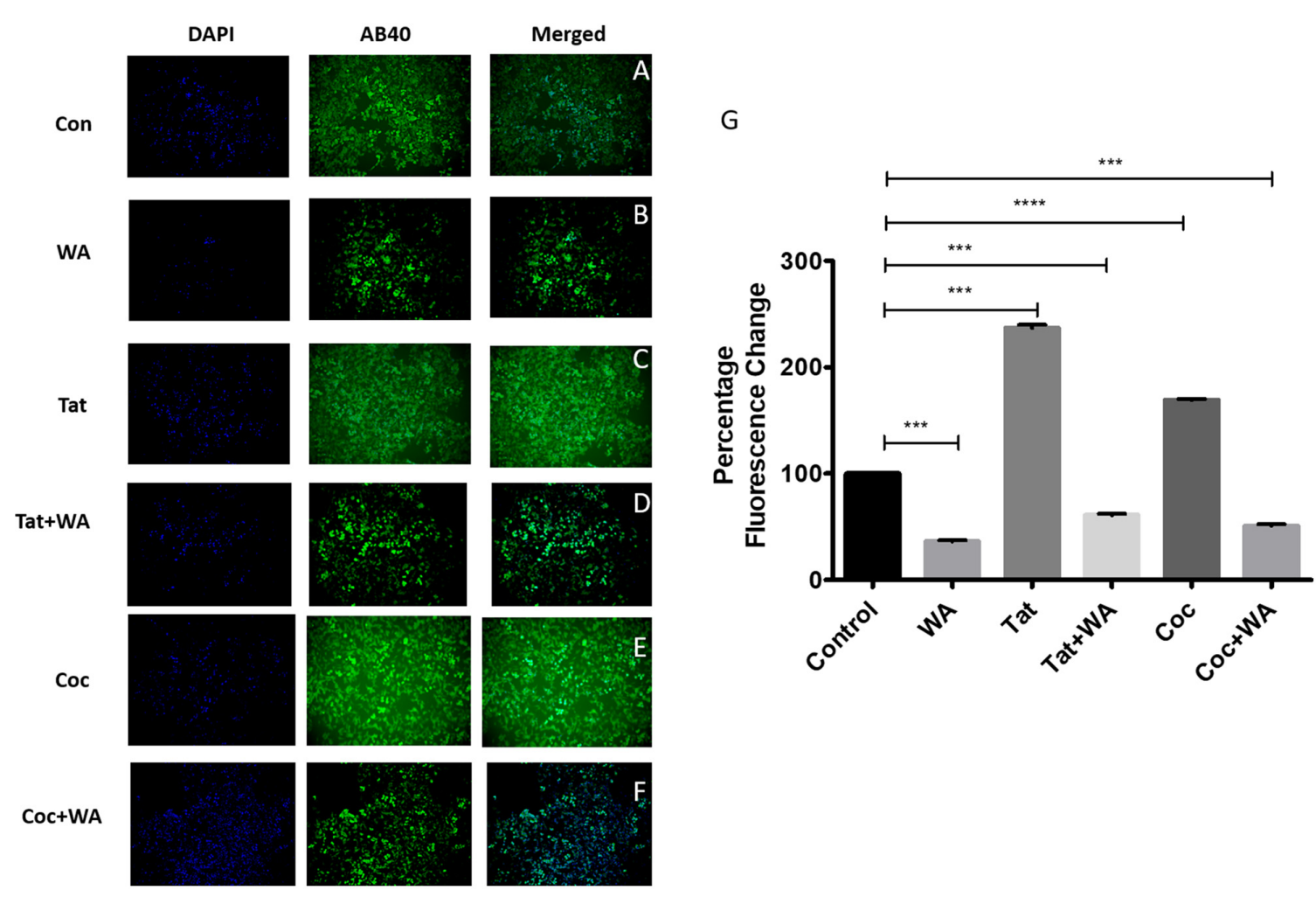

FIGURE 9 | WA inhibits HIV-1 Tat induced A -production, respectively. SH-APP cells were treated with HIV-1 Tat (50 ng/mL; C) coc (0.1 $\mu \mathrm{M} ; \mathbf{E})+/-$ WA (2 $\mu \mathrm{M}$; (D,F) respectively) were compared to Control (A) and only WA treated cells (B). After $24 \mathrm{~h}$, cells were fixed and stained with Anti-Human AB40 overnight. Cells were washed and stained with secondary anti-rabbit FITC-labeled antibody (catalog \#AP187F, Millipore). Images were acquired using Keyence ALL in one microscope $(10 \times)$. WA significantly suppressed Tat and coc induced A $\beta$-secretion, respectively $(n=3)$. Florescent intensity of these stained cells was quantified using the Image software $\left(\mathbf{G} ;{ }^{* * *} p \leq 0.001 ;{ }^{* * * *} p \leq 0.0001\right)$.

conducted immunofluorescence imaging experiment. Cultures of SH-APP cells grown on the eight well imaging slides for $48 \mathrm{~h}$, and then the cells were stained by MAP2 primary antibody. We observed that the cells exposed to coc for $48 \mathrm{~h}$ exhibited heavy dendritic beading (indicated by yellow arrows) and cytoplasmic vacuoles (Figure 10C). The control SH-APP cells (Figure 10A) and WA only treated cells (Figure 10B) showed no abnormal beading or thickening of the dendrites, when compared. Upon treatment with WA, in coc exposed cells (Figure 10D), we observed reduced dendritic beading and more pronounced and elongated dendrites, communicating with other neuronal cells. We also observed reduced cytoplasmic vacuoles in the WA treated cells. This indicates that coc induces the stressed environment in the cell culture system which leads to neuronal damage (Figure 10).

\section{DISCUSSION}

Currently, the studies focusing towards neurodegeneration caused by either aging or due to viral infections, are extremely important. The accumulation of $\mathrm{A} \beta$ in the CNS is major factor contributing towards neurodegeneration (Green et al., 2005). The introduction of HAART gives a longer life span, giving a major opportunity to age related disorders in these recovering patients (Ellis et al., 2010; Heaton et al., 2010, 2011). The currently available drugs against $\mathrm{A} \beta$ aggregation, for example, Memantine ( $N$-methyl-D-aspartic acid (NMDA) receptor antagonist), helps in repair of damaged neurons (van Marum, 2008), but does not aid in overall cure for neurological issues. Another drug which is very well studied for its antiinflammatory, antioxidant and neuroprotective properties is Cucurmin/Curcuminoid, obtained from the roots of a plant Curcuma longa (Sharma et al., 2007). It has been reported that Curcuma may have potential role in $\mathrm{AD}$ treatment by targeting $A \beta$ aggregates and associated toxicity in the neuronal cells (Ringman et al., 2005; Ishrat et al., 2009). Unfortunately, Curcuma is weakly stable and easily hydrolyzed, and gets photodegraded or even oxidized. This makes it very challenging and leads to its minimal bioavailability in the CNS (Anand et al., 2007).

Currently, there is no direct cure available for $\mathrm{AD}$ or AD-like neurodegenerative symptoms. Therefore in this paper we have focused on a drug compound WA, as a neuroprotective agent against $A \beta$ induced neuronal toxicity. Our studies show that WA reduces the levels of secreted $A \beta$ significantly without causing cytotoxicity in the cell cultures. Our microscopic studies demonstrate the protective role of WA as the human neuroblastoma cells showed healthy growth in the presence of 

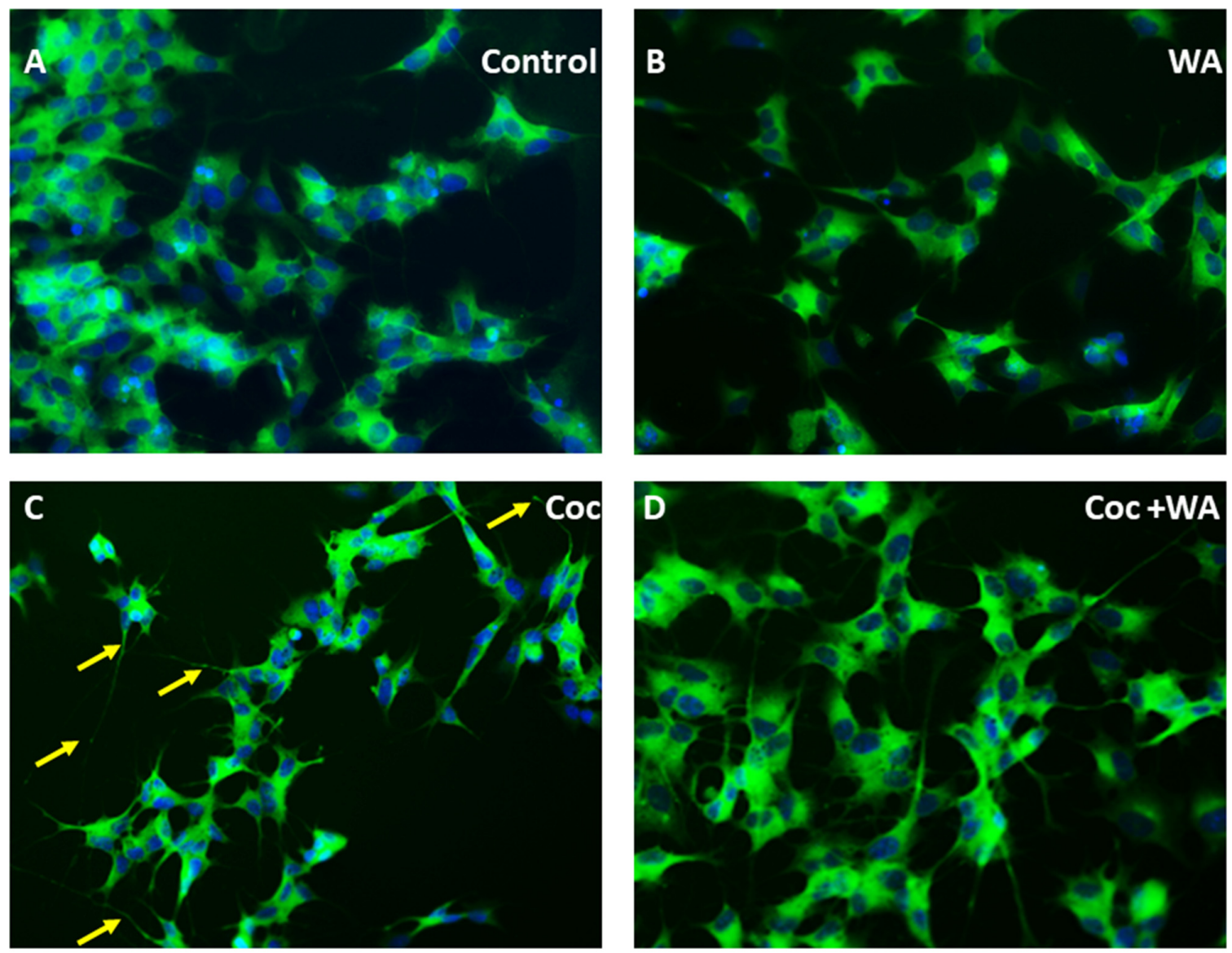

FIGURE 10 |WA reverses coc induced dendritic beading and cytoplasmic vacuoles. SH-APP cells were treated with coc $(0.1 \mu \mathrm{M})+/-\mathrm{WA}(2 \mu \mathrm{M})$. After $24 \mathrm{~h}$, cells were fixed and stained with MAP2 primary antibody overnight. Cells were washed and stained with secondary anti-rabbit FITC-labeled antibody (catalog \#AP187F, Millipore). (A) Control SH-APP cells and (B) WA only treated cells showed no abnormal beading or thickening of the dendrites when compared to (C) coc exposed SH-APP cells which exhibited heavy dendritic beading (yellow arrows) and cytoplasmic vacuoles, measure of the cells being in drug-induced stress, (D) WA treated coc exposed cells on the other HIV-1 associated neurocognitive disorder (HAND) displayed reduced dendritic beading and elongated dendrites, with minimal cytoplasmic vacuoles.

WA. We observed that WA treatment reduced dendritic beading and cytoplasmic vacuoles in the SH-APP cells, conferring towards protective role of WA. Our observation coincides with other studies as well, which show that $W$. somnifera whole root extract treatment promotes neuronal health by inducing dendrite formation in vitro (Tohda et al., 2000; Zhao et al., 2002). Moreover, our study shows for the first time that a small sized active moiety of Withania root extract, termed as WA neutralizes secreted $A \beta$, in the SH-APP cells in vitro. Our previous lab has studied the role of Ashwagandha (ASH) which is a big molecule extracted from roots of $W$. Somnifera. We reported the properties of $\mathrm{ASH}$ towards neutralizing $\mathrm{A} \beta$ in the neuronal cells in vitro. ASH showed the reduction of $A \beta$ in treated cells significantly when compared to untreated controls, suggesting anti-amyloid role of ASH (Kurapati et al., 2013, 2014). Even though ASH is capable of reducing the secreted $A \beta$, the understanding of ASH's efficacy in the CNS across the BBB is minimum, as it is a big moiety. Therefore, the systematic delivery of the drug into the CNS and increased bioavailability becomes a pressing issue. This urged a need to find potent smaller molecular weight molecules with similar properties. Systematic chromatographic studies show the various components, upon breakdown of ASH molecule. This gave us an opportunity to study small molecule WA and assess its ability as a neuroprotectant to target the $\mathrm{A} \beta$ levels.

We further wanted to explore the effect of WA on induced $\mathrm{A} \beta$ production by the exposure of HIV-1 Tat. Therefore, in this study, we have analyzed the effect of HIV-1 Tat protein (Nuovo et al., 1994; Nath et al., 1996; Merino et al., 2011) on the $\mathrm{A} \beta$ secretion in SH-APP neuronal cells and found significantly increased $A \beta$ production. Our results are in agreement with other studies which have reported the role of Tat protein in increased neuronal $\mathrm{A} \beta$ secretion (Rempel and Pulliam, 2005; Giunta et al., 2009; Aksenov et al., 2010). Tat is a neurotoxin and we show that it aggravates the $\mathrm{A} \beta$ aggregation in vitro. The mechanism through which this happens is still not understood well (Chen et al., 2013; Hategan et al., 2017), Tat may have a direct interaction with the $\mathrm{A} \beta$ fibrils, resulting in induced 
aggregation of monomers, towards plaques. This hypothesis is supported by our Immunocytochemistry studies which show dense accumulation of $A \beta$, in the cell medium exposed to HIV-1Tat (50 ng/ml). Our human A $\beta 40$ ELISA experiment detected increased concentration of $A \beta$ in Tat treated samples as well. This leads us to a conclusion that Tat is extremely neurotoxic and has an ability to interact with $A \beta$, increasing the overall toxicity of the cell system, and urging more and more release and aggravation of A 3 . HIV-1 Tat tends to have a direct physical interaction with $A \beta$ peptide, leading to excessive aggregation of $A \beta$ leading to neurotoxicity (Hategan et al., 2017).

Further, among the most abused drugs by People living with HIV (PLWH), coc abuse has been one of the major contributors towards the increased severity of neurocognitive disorders in the patients (Fiala et al., 1998; Gannon et al., 2011; Buch et al., 2012). Additionally, the percentage of drug abusers in the HIV positive population and aging population is very high. Drug abuse/addiction and HIV/AIDS are linked since the beginning of the HIV/AIDS epidemic. People who inject drugs accounted for about six percent of HIV diagnoses in 2015 (CDC, 2018). Even though the association of coc is shown with the exaggeration in HIV neuropathogenesis, the underlying mechanisms remain unclear. We elucidate the mechanism, in this study, for the first time, we observed the increased levels of $A \beta$ production by coc. We also observed in our Immunocytochemistry experiments that $\operatorname{coc}$ affects neuronal morphology and communications, and aggregation of $\mathrm{A} \beta$ in the SH-APP cells, in vitro. This verifies the toxic effect of $\operatorname{coc}$ on the neuronal cells, which contribute in the increased accumulation of the amyloids. Coc alone and in combination with HIV-1 Tat is highly neurotoxic. These results coincide with various in vivo studies done by other research groups which show that the peritoneal injection of $\operatorname{coc}$ in rats stimulates hyperphosphorylation of tau and neurofilament in cortex, hippocampus and caudato-putamen regions of brain, indirectly contributing to the $A \beta$ toxicity (Liu et al., 2003). These observations indicate that coc addiction may be associated with neurofibrillary degeneration. Therefore, here we report that $\operatorname{coc}$ in addition to HIV-1 Tat increases A $\beta$ secretion in vitro. Our findings suggest that HIV-1 Tat and coc introduce cellular toxicity and cause neuronal dysfunctions by increasing amyloid secretion and modulating neuronal morphology and communications. Moreover, accumulation and deposition of $A \beta$ in the brain of HIV patients (active infection or latent infection) drive the pathogenic cascades of neurological disorders, contributing towards aging or associated dementias (Pulliam, 2009). Targeting A $\beta$ secretion, will have a translational significance in the treatment of HIV coc abusers and other neurological disorders like $\mathrm{AD}$.

\section{REFERENCES}

Achim, C. L., Adame, A., Dumaop, W., Everall, I. P., Masliah, E., and Neurobehavioral Research Center. (2009). Increased accumulation of intraneuronal amyloid $\beta$ in HIV-infected patients. J. Neuroimmune Pharmacol. 4, 190-199. doi: 10.1007/s11481-009-9152-8

Ahyayauch, H., Raab, M., Busto, J. V., Andraka, N., Arrondo, J.-L. R., Masserini, M., et al. (2012). Binding of $\beta$-amyloid (1-42) peptide to negatively
Additionally, the main rationale behind introducing WA is the unavailability of the direct medicine/drugs which target neurological disorders. Moreover the drugs, get rejected due to pharmacotherapy failures like inadequate physical chemistry, minimal absorption, unfavorable pharmacokinetic parameters, instability and toxicity. This urges the need of the alternate medicine/nanomedicine. Therefore, our next step is to address the limitation or incapability of drugs to cross BBB into the CNS, by employing nanotechnology assisted approaches, where our developed drug magneto-liposomes (which are a biopolymeric vesicle with capacity to deliver drugs across $\mathrm{BBB}$ ) would be able to transmigrate across BBB (Ding et al., 2014; Kaushik et al., 2016).

In summary, it is critical to design and identify compounds that specifically target and inhibit $A \beta$ secretion and aggregation, and also the interaction between $A \beta$ and HIV-Tat 1 and drug of abuse, against their synergistic role towards neurodegenerative disorders. When combined with other strategies targeting $\mathrm{A} \beta$, including immunotherapy, these approaches might allow for a reduction, if not elimination, of $\mathrm{A} \beta$-related toxicity. Further in vivo efficacy and drug delivery mechanistic studies are necessary to explore WA's therapeutic role in neurological disorders like HIV associated neurocognitive disorders and Alzheimer's disease.

\section{AUTHOR CONTRIBUTIONS}

ST designed and coordinated the research, performed experiments, data analysis and manuscript writing. AYA helped in flow cytometry experiments and analysis. VA and RJ helped in data analysis and manuscript review. AK helped in manuscript review. JG reviewed the manuscript. MN guided in experimental research plan and provided continuous supervision and reviewed the manuscript.

\section{FUNDING}

The National Institute of Health (Grant\# R01DA034547), Florida Department of Health's Ed, and Ethel Moore Alzheimer's Disease Research Program (Grant\# 800009191) supported this work.

\section{ACKNOWLEDGMENTS}

We would like to acknowledge the Dissertation Year Fellowship 2018 awarded to ST (graduate student) by University Graduate School, Florida International University.

charged phospholipid membranes in the liquid-ordered state: modeling and experimental studies. Biophys. J. 103, 453-463. doi: 10.1016/j.bpj.2012.06.043

Aksenov, M., Aksenova, M., Mactutus, C., and Booze, R. (2010). HIV-1 proteinmediated amyloidogenesis in rat hippocampal cell cultures. Neurosci. Lett. 475, 174-178. doi: 10.1016/j.neulet.2010.03.073

Anand, P., Kunnumakkara, A. B., Newman, R. A., and Aggarwal, B. B. (2007). Bioavailability of curcumin: problems and promises. Mol. Pharm. 4, 807-818. doi: $10.1021 / \mathrm{mp} 700113 \mathrm{r}$ 
András, I. E., and Toborek, M. (2013). Amyloid beta accumulation in HIV-1infected brain: the role of the blood brain barrier. IUBMB Life 65, 43-49. doi: 10.1002/iub.1106

Arimon, M., Takeda, S., Post, K. L., Svirsky, S., Hyman, B. T., and Berezovska, O. (2015). Oxidative stress and lipid peroxidation are upstream of amyloid pathology. Neurobiol. Dis. 84, 109-119. doi: 10.1016/j.nbd.2015.06.013

Bagashev, A., and Sawaya, B. E. (2013). Roles and functions of HIV-1 Tat protein in the CNS: an overview. Virol. J. 10:358. doi: 10.1186/1743-422X-10-358

Barage, S. H., and Sonawane, K. D. (2015). Amyloid cascade hypothesis: pathogenesis and therapeutic strategies in Alzheimer's disease. Neuropeptides 52, 1-18. doi: 10.1016/j.npep.2015.06.008

Bargagna-Mohan, P., Hamza, A., Kim, Y.-E., Ho, Y. K. A., Mor-Vaknin, N., Wendschlag, N., et al. (2007). The tumor inhibitor and antiangiogenic agent withaferin A targets the intermediate filament protein vimentin. Chem. Biol. 14, 623-634. doi: 10.1016/j.chembiol.2007.04.010

Becker, J. T., Lopez, O. L., Dew, M. A., and Aizenstein, H. J. (2004). Prevalence of cognitive disorders differs as a function of age in HIV virus infection. AIDS 18, 11-18. doi: 10.1097/00002030-200401001-00003

Buch, S., Yao, H., Guo, M., Mori, T., Mathias-Costa, B., Singh, V., et al. (2012). Cocaine and HIV-1 interplay in CNS: cellular and molecular mechanisms. Curr. HIV Res. 10, 425-428. doi: 10.2174/157016212802138823

Butterfield, D. A., Swomley, A. M., and Sultana, R. (2013). Amyloid $\beta$-peptide (1-42)-induced oxidative stress in alzheimer disease: importance in disease pathogenesis and progression. Antioxid. Redox Signal. 19, 823-835. doi: 10.1089/ars.2012.5027

CDC. (2018). Injection Drug Use and HIV Risk. Available online at: https://www.cdc.gov/hiv/risk/idu.html

Challa, A. A., Vukmirovic, M., Blackmon, J., and Stefanovic, B. (2012). WithaferinA reduces type I collagen expression in vitro and inhibits development of myocardial fibrosis in vivo. PLoS One 7:e42989. doi: 10.1371/journal.pone. 0042989

Chandra, T., Maier, W., König, H.-G., Hirzel, K., Kögel, D., Schüler, T., et al. (2005). Molecular interactions of the type 1 human immunodeficiency virus transregulatory protein Tat with $N$-methyl-d-aspartate receptor subunits. Neuroscience 134, 145-153. doi: 10.1016/j.neuroscience.2005.02.049

Cheignon, C., Tomas, M., Bonnefont-Rousselot, D., Faller, P., Hureau, C., and Collin, F. (2018). Oxidative stress and the amyloid beta peptide in Alzheimer's disease. Redox Biol. 14, 450-464. doi: 10.1016/j.redox.2017.10.014

Chen, X., Hui, L., Geiger, N. H., Haughey, N. J., and Geiger, J. D. (2013). Endolysosome involvement in HIV-1 transactivator protein-induced neuronal amyloid beta production. Neurobiol. Aging 34, 2370-2378. doi: 10.1016/j. neurobiolaging.2013.04.015

Choi, B. Y., and Kim, B.-W. (2015). Withaferin-A inhibits colon cancer cell growth by blocking STAT3 transcriptional activity. J. Cancer Prev. 20, 185-192. doi: 10.15430/JCP.2015.20.3.185

Daily, A., Nath, A., and Hersh, L. B. (2006). Tat peptides inhibit neprilysin. J. Neurovirol. 12, 153-160. doi: 10.1080/13550280600760677

Ding, H., Sagar, V., Agudelo, M., Pilakka-Kanthikeel, S., Atluri, V. S. R., Raymond, A., et al. (2014). Enhanced blood-brain barrier transmigration using a novel transferrin embedded fluorescent magneto-liposome nanoformulation. Nanotechnology 25:055101. doi: 10.1088/0957-4484/25/5/055101

Dorszewska, J., Prendecki, M., Oczkowska, A., Dezor, M., and Kozubski, W. (2016). Molecular basis of familial and sporadic Alzheimer's disease. Curr. Alzheimer Res. 13, 952-963. doi: 10.2174/1567205013666160314150501

Dublin, S., Walker, R. L., Gray, S. L., Hubbard, R. A., Anderson, M. L., Yu, O., et al. (2017). Use of analgesics (opioids and nonsteroidal anti-inflammatory drugs) and dementia-related neuropathology in a community-based autopsy cohort. J. Alzheimers Dis. 58, 435-448. doi: 10.3233/JAD-160374

Echeverria, V., Ducatenzeiler, A., Dowd, E., Jänne, J., Grant, S. M., Szyf, M., et al. (2004). Altered mitogen-activated protein kinase signaling, tau hyperphosphorylation and mild spatial learning dysfunction in transgenic rats expressing the $\beta$-amyloid peptide intracellularly in hippocampal and cortical neurons. Neuroscience 129, 583-592. doi: 10.1016/j.neuroscience.2004.07.036

Ellis, R. J., Rosario, D., Clifford, D. B., Mcarthur, J. C., Simpson, D., Alexander, T., et al. (2010). Continued high prevalence and adverse clinical impact of human immunodeficiency virus-associated sensory neuropathy in the era of combination antiretroviral therapy: the CHARTER study. Arch. Neurol. 67, 552-558. doi: 10.1001/archneurol.2010.76
Esiri, M. M., Biddolph, S. C., and Morris, C. S. (1998). Prevalence of Alzheimer plaques in AIDS. J. Neurol. Neurosurg. Psychiatry 65, 29-33. doi: 10.1136/jnnp. 65.1 .29

Fiala, M., Gan, X. H., Zhang, L., House, S. D., Newton, T., Graves, M. C., et al. (1998). Cocaine enhances monocyte migration across the blood-brain barrier. Cocaine's connection to AIDS dementia and vasculitis? Adv. Exp. Med. Biol. 437, 199-205. doi: 10.1007/978-1-4615-5347-2_22

Gannon, P., Khan, M. Z., and Kolson, D. L. (2011). Current understanding of HIV-associated neurocognitive disorders pathogenesis. Curr. Opin. Neurol. 24, 275-283. doi: 10.1097/WCO.0b013e32834695fb

Ghosh, A. K., Gemma, S., and Tang, J. (2008). $\beta$-secretase as a therapeutic target for Alzheimer's disease. Neurotherapeutics 5, 399-408. doi: 10.1016/j.nurt.2008. 05.007

Giunta, B., Hou, H., Zhu, Y., Rrapo, E., Tian, J., Takashi, M., et al. (2009). HIV-1 Tat contributes to Alzheimer's disease-like pathology in PSAPP mice. Int. J. Clin. Exp. Pathol. 2, 433-443.

Green, D. A., Masliah, E., Vinters, H. V., Beizai, P., Moore, D. J., and Achim, C. L. (2005). Brain deposition of beta-amyloid is a common pathologic feature in HIV positive patients. AIDS 19, 407-411. doi: 10.1097/01.aids.0000161770. $06158.5 \mathrm{c}$

Guardia-Laguarta, C., Pera, M., and Lleo, A. (2010). $\gamma$-Secretase as a therapeutic target in Alzheimers disease. Curr. Drug Targets 11, 506-517. doi: 10.2174/138945010790980349

Hategan, A., Bianchet, M. A., Steiner, J., Karnaukhova, E., Masliah, E., Fields, A., et al. (2017). HIV Tat protein and amyloid- $\beta$ peptide form multifibrillar structures that cause neurotoxicity. Nat. Struct. Mol. Biol. 24, 379-386. doi: $10.1038 / \mathrm{nsmb} .3379$

Heaton, R., Clifford, D., Franklin, D., Woods, S., Ake, C., Vaida, F., et al. (2010). HIV-associated neurocognitive disorders persist in the era of potent antiretroviral therapy CHARTER study. Neurology 75, 2087-2096. doi: 10.1212/WNL.0b013e318200d727

Heaton, R. K., Franklin, D. R., Ellis, R. J., McCutchan, J. A., Letendre, S. L., Leblanc, S., et al. (2011). HIV-associated neurocognitive disorders before and during the era of combination antiretroviral therapy: differences in rates, nature and predictors. J. Neurovirol. 17, 3-16. doi: 10.1007/s13365-010-0006-1

Ishrat, T., Hoda, M. N., Khan, M. B., Yousuf, S., Ahmad, M., Khan, M. M., et al. (2009). Amelioration of cognitive deficits and neurodegeneration by curcumin in rat model of sporadic dementia of Alzheimer's type (SDAT). Eur. Neuropsychopharmacol. 19, 636-647. doi: 10.1016/j.euroneuro.2009. 02.002

Javadi-Paydar, M., Roscoe, R. F. Jr., Denton, A. R., Mactutus, C. F., and Booze, R. M. (2017). HIV-1 and cocaine disrupt dopamine reuptake and medium spiny neurons in female rat striatum. PLoS One 12:e0188404. doi: 10.1371/journal.pone.0188404

Jayant, R. D., Atluri, V. S., Tiwari, S., Pilakka-Kanthikeel, S., Kaushik, A., Yndart, A., et al. (2017). Novel nanoformulation to mitigate co-effects of drugs of abuse and HIV-1 infection: towards the treatment of NeuroAIDS. J. Neurovirol. 23, 603-614. doi: 10.1007/s13365-017-0538-8

Kaushik, A., Jayant, R. D., Tiwari, S., Vashist, A., and Nair, M. (2016). Nanobiosensors to detect beta-amyloid for Alzheimer's disease management. Biosens Bioelectron. 80, 273-287. doi: 10.1016/j.bios.2016.01.065

Koppel, B. S., Wormser, G. P., Tuchman, A. J., Maayan, S., Hewlett, D. Jr., et al. (1985). Central nervous system involvement in patients with acquired immune deficiency syndrome (AIDS). Acta Neurol. Scand. 71, 337-353. doi: 10.1111/j. 1600-0404.1985.tb03211.x

Kretner, B., Trambauer, J., Fukumori, A., Mielke, J., Kuhn, P. H., Kremmer, E., et al. (2016). Generation and deposition of $\mathrm{A} \beta 43$ by the virtually inactive presenilin-1 L435F mutant contradicts the presenilin loss-of-function hypothesis of Alzheimer's disease. EMBO Mol. Med. 8, 458-465. doi: 10.15252/ emmm.201505952

Kurapati, K. R., Atluri, V. S., Samikkannu, T., and Nair, M. P. (2013). Ashwagandha (Withania somnifera) reverses beta-amyloid1-42 induced toxicity in human neuronal cells: implications in HIV-associated neurocognitive disorders (HAND). PLoS One 8:e77624. doi: 10.1371/journal. pone.0077624

Kurapati, K. R., Samikkannu, T., Atluri, V. S., Kaftanovskaya, E., Yndart, A., and Nair, M. P. (2014). $\beta$-Amyloid1-42, HIV-1Ba-L (clade B) infection and drugs of abuse induced degeneration in human neuronal cells and protective effects 
of ashwagandha (Withania somnifera) and its constituent Withanolide A. PLoS One 9:e112818. doi: 10.1371/journal.pone.0112818

Lee, I.-C., and Choi, B. Y. (2016). Withaferin-A-a natural anticancer agent with pleitropic mechanisms of action. Int. J. Mol. Sci. 17:290. doi: $10.3390 /$ ijms 17030290

Li, Y., Sun, Z., Cao, Q., Chen, M., Luo, H., Lin, X., et al. (2017). Role of amyloid $\beta$ protein receptors in mediating synaptic plasticity. Biomed. Rep. 6, 379-386. doi: 10.3892/br.2017.863

Liu, S.-J., Fang, Z.-Y., Yang, Y., Deng, H.-M., and Wang, J.-Z. (2003). Alzheimerlike phosphorylation of tau and neurofilament induced by cocaine in vivo. Acta Pharmacol. Sin. 24, 512-518.

Marottoli, F. M., Katsumata, Y., Koster, K. P., Thomas, R., Fardo, D. W., and Tai, L. M. (2017). Peripheral inflammation, apolipoprotein E4 and amyloid$\beta$ interact to induce cognitive and cerebrovascular dysfunction. ASN Neuro 9:1759091417719201. doi: 10.1177/1759091417719201

Martínez-Bonet, M., Muñoz-Fernández, M. A., and Álvarez, S. (2018). HIV-1 increases extracellular amyloid-beta levels through neprilysin regulation in primary cultures of human astrocytes. J. Cell. Physiol. doi: 10.1002/jcp.26462 [Epub ahead of print].

Meade, C. S., Hobkirk, A. L., Towe, S. L., Chen, N.-K., Bell, R. P., and Huettel, S. A. (2017). Cocaine dependence modulates the effect of HIV infection on brain activation during intertemporal decision making. Drug Alcohol Depend. 178, 443-451. doi: 10.1016/j.drugalcdep.2017.05.043

Merino, J. J., Montes, M., Blanco, A., Bustos, M. J., Oreja-Guevara, C., Bayon, C., et al. (2011). HIV-1 neuropathogenesis: therapeutic strategies against neuronal loss induced by gp120/Tat glycoprotein in the central nervous system. Rev. Neurol. 52, 101-111.

Mirjalili, M. H., Moyano, E., Bonfill, M., Cusido, R. M., and Palazón, J. (2009). Steroidal lactones from Withania somnifera, an ancient plant for novel medicine. Molecules 14, 2373-2393. doi: 10.3390/molecules14072373

Mohan, R., and Bargagna-Mohan, P. (2016). The use of withaferin A to study intermediate filaments. Methods Enzymol. 568, 187-218. doi: 10.1016/bs.mie. 2015.09.025

Mohan, R., Hammers, H., Bargagna-Mohan, P., Zhan, X., Herbstritt, C., Ruiz, A., et al. (2004). Withaferin A is a potent inhibitor of angiogenesis. Angiogenesis 7, 115-122. doi: 10.1007/s10456-004-1026-3

Nath, A., Psooy, K., Martin, C., Knudsen, B., Magnuson, D., Haughey, N., et al. (1996). Identification of a human immunodeficiency virus type 1 Tat epitope that is neuroexcitatory and neurotoxic. J. Virol. 70, 1475-1480.

Nuovo, G. J., Becker, J., Burk, M. W., Margiotta, M., Fuhrer, J., and Steigbigel, R. T. (1994). in situ detection of PCR-amplified HIV-1 nucleic acids in lymph nodes and peripheral blood in patients with asymptomatic HIV-1 infection and advanced-stage AIDS. J. Acquir. Immune Defic. Syndr. 7, 916-923.

Oguntibeju, O. O. (2012). Quality of life of people living with HIV and AIDS and antiretroviral therapy. HIV/AIDS 4, 117-124. doi: 10.2147/HIV.s32321

Palop, J. J., and Mucke, L. (2010). Amyloid- $\beta$ induced neuronal dysfunction in Alzheimer's disease: from synapses toward neural networks. Nat. Neurosci. 13, 812-818. doi: $10.1038 / \mathrm{nn} .2583$

Park, H. J., Rayalam, S., Della-Fera, M. A., Ambati, S., Yang, J.-Y., and Baile, C. A. (2008). Withaferin A induces apoptosis and inhibits adipogenesis in 3T3-L1 adipocytes. Biofactors 33, 137-148. doi: 10.1002/biof.5520 330206

Pulliam, L. (2009). HIV regulation of amyloid beta production. J. Neuroimmune Pharmacol. 4, 213-217. doi: 10.1007/s11481-009-9151-9

Rah, B., Amin, H., Yousuf, K., Khan, S., Jamwal, G., Mukherjee, D., et al. (2012). A novel MMP-2 inhibitor 3-azidowithaferin A (3-azidoWA) abrogates cancer cell invasion and angiogenesis by modulating extracellular Par-4. PLoS One 7:e44039. doi: 10.1371/journal.pone.0044039

Ramage, S., Anthony, I., Carnie, F., Busuttil, A., Robertson, R., and Bell, J. (2005). Hyperphosphorylated tau and amyloid precursor protein deposition is increased in the brains of young drug abusers. Neuropathol. Appl. Neurobiol. 31, 439-448. doi: 10.1111/j.1365-2990.2005.00670.x

Rempel, H. C., and Pulliam, L. (2005). HIV-1 Tat inhibits neprilysin and elevates amyloid $\beta$. AIDS 19, 127-135. doi: 10.1097/00002030-200501280-00004

Ringman, J. M., Frautschy, S. A., Cole, G. M., Masterman, D. L., and Cummings, J. L. (2005). A potential role of the curry spice curcumin in Alzheimer's disease. Curr. Alzheimer Res. 2, 131-136. doi: 10.2174/ 1567205053585882
Levy, R. M., Bredesen, D. E., and Rosenblum, M. L. (1985). Neurological manifestations of the acquired immunodeficiency syndrome (AIDS): experience at UCSF and review of the literature. J. Neurosurg. 62, 475-495. doi: 10.3171/jns.1985.62.4.0475

Sabin, C. A. (2013). Do people with HIV infection have a normal life expectancy in the era of combination antiretroviral therapy? BMC Med. 11:251. doi: 10.1186/1741-7015-11-251

Saylor, D., Dickens, A. M., Sacktor, N., Haughey, N., Slusher, B., Pletnikov, M., et al. (2016). HIV-associated neurocognitive disorder-pathogenesis and prospects for treatment. Nat. Rev. Neurol. 12, 234-248. doi: 10.1038/nrneurol. 2016.27

Sharma, R. A., Steward, W. P., and Gescher, A. J. (2007). Pharmacokinetics and pharmacodynamics of curcumin. Adv. Exp. Med. Biol. 595, 453-470. doi: 10.1007/978-0-387-46401-5_20

Snider, W. D., Simpson, D. M., Nielsen, S., Gold, J. W., Metroka, C. E., and Posner, J. B. (1983). Neurological complications of acquired immune deficiency syndrome: analysis of 50 patients. Ann. Neurol. 14, 403-418. doi: 10.1002/ana. 410140404

Soontornniyomkij, V., Moore, D. J., Gouaux, B., Soontornniyomkij, B., Tatro, E. T., Umlauf, A., et al. (2012). Cerebral $\beta$-amyloid deposition predicts HIV-associated neurocognitive disorders in APOE $\varepsilon 4$ carriers. AIDS 26, 2327-2335. doi: 10.1097/QAD.0b013e32835a117c

Tahirov, T. H., Babayeva, N. D., Varzavand, K., Cooper, J. J., Sedore, S. C., and Price, D. H. (2010). Crystal structure of HIV-1 Tat complexed with human P-TEFb. Nature 465, 747-751. doi: 10.1038/nature09131

Tohda, C., Kuboyama, T., and Komatsu, K. (2000). Dendrite extension by methanol extract of Ashwagandha (roots of Withania somnifera) in SK-N-SH cells. Neuroreport 11, 1981-1985. doi: 10.1097/00001756-200006260-00035

Valcour, V. G., Shikuma, C. M., Watters, M. R., and Sacktor, N. C. (2004). Cognitive impairment in older HIV-1-seropositive individuals: prevalence and potential mechanisms. AIDS 18, 79-86. doi: 10.1097/00002030-20041800100012

van Marum, R. J. (2008). Current and future therapy in Alzheimer's disease. Fundam. Clin. Pharmacol. 22, 265-274. doi: 10.1111/j.1472-8206.2008. 00578.x

Venkitaramani, D. V., Chin, J., Netzer, W. J., Gouras, G. K., Lesne, S., Malinow, R., et al. (2007). $\beta$-amyloid modulation of synaptic transmission and plasticity. J. Neurosci. 27, 11832-11837. doi: 10.1523/JNEUROSCI.3478-07.2007

Wakim, K.-M., Molloy, C. J., Bell, R. P., Ross, L. A., and Foxe, J. J. (2017). White matter changes in HIV+ women with a history of cocaine dependence. Front. Neurol. 8:562. doi: 10.3389/fneur.2017.00562

World Health Organization (2016). Global Aids Update. Available online at: http://www.who.int/hiv/pub/arv/global-AIDS-update-2016_en.pdf

World Health Organization (2018). HIV/AIDS. Available online at: http://www. who.int/mediacentre/factsheets/fs360/en/

Yu, Y., Hamza, A., Zhang, T., Gu, M., Zou, P., Newman, B., et al. (2010). Withaferin A targets heat shock protein 90 in pancreatic cancer cells. Biochem. Pharmacol. 79, 542-551. doi: 10.1016/j.bcp.2009.09.017

Zhao, J., Nakamura, N., Hattori, M., Kuboyama, T., Tohda, C., and Komatsu, K. (2002). Withanolide derivatives from the roots of Withania somnifera and their neurite outgrowth activities. Chem. Pharm. Bull. 50, 760-765. doi: 10.1248/cpb. 50.760

Zheng, W. H., Bastianetto, S., Mennicken, F., Ma, W., and Kar, S. (2002). Amyloid $\beta$ peptide induces tau phosphorylation and loss of cholinergic neurons in rat primary septal cultures. Neuroscience 115, 201-211. doi: 10.1016/s03064522(02)00404-9

Conflict of Interest Statement: The authors declare that the research was conducted in the absence of any commercial or financial relationships that could be construed as a potential conflict of interest.

Copyright $\odot 2018$ Tiwari, Atluri, Yndart Arias, Jayant, Kaushik, Geiger and Nair. This is an open-access article distributed under the terms of the Creative Commons Attribution License (CC BY). The use, distribution or reproduction in other forums is permitted, provided the original author(s) and the copyright owner(s) are credited and that the original publication in this journal is cited, in accordance with accepted academic practice. No use, distribution or reproduction is permitted which does not comply with these terms. 